\title{
Photo-induced self-formation of dual-cocatalysts on semiconductor surface
}

\author{
Linchao Mu a,b, Qiao Zhang a, Xiaoping Tao a, Yue Zhao a,b, Shengyang Wang a,b, Junyan Cui a, \\ Fengtao Fan a, Can Li a,* \\ a State Key Laboratory of Catalysis, Dalian National Laboratory for Clean Energy, and the Collaborative Innovation Center of Chemistry for Energy \\ Materials (iChEM), Dalian Institute of Chemical Physics, Chinese Academy of Sciences, Dalian 116023, Liaoning, China \\ b University of Chinese Academy of Sciences, Beijing 100049, China
}

\section{A R T I C L E I N F O}

Article history:

Received 28 June 2018

Accepted 16 July 2018

Published 5 November 2018

\section{Keywords:}

Photocatalysis

Cocatalyst

Chemical state

Photogenerated charges

Self-formation

\begin{abstract}
A B S T R A C T
Cocatalyst plays key roles in photogenerated charge separation and surface catalytic reactions in photocatalysis. However, it is not clear if the chemical states of cocatalysts changed or remains unchanged under photocatalytic reaction conditions. Herein, taking $\mathrm{NaTaO}_{3}$ as an example, we systemically investigated the chemical states of nickel-based cocatalysts during photocatalytic water splitting reaction. It was found that photo-induced self-formation of $\mathrm{Ni}$ and $\mathrm{NiO}$ cocatalyst species take place on the surface of $\mathrm{NaTaO}_{3}$ nanocrystals. The self-formation of dual-cocatalysts not only occurs on 26-facet $\mathrm{NaTaO}_{3}$, but also takes place on a more general 6-facet $\mathrm{NaTaO}_{3}$. Our work clarified that the chemical states of cocatalysts are changing and the redox dual-cocatalysts are redistributed on the semiconductor surface owing to the reaction induced by photogenerated charges under the condition of photocatalytic reactions.
\end{abstract}

(C) 2018, Dalian Institute of Chemical Physics, Chinese Academy of Sciences. Published by Elsevier B.V. All rights reserved.
Photogenerated charge separation and surface catalytic reactions are prerequisites for photocatalysis, in particular for photocatalytic overall water splitting [1-8]. Proper cocatalysts can serve as active sites for surface reactions and improve charge separation and charge utilization $[9,10]$. An interesting issue concerning cocatalysts is the chemical state of cocatalysts, which is not clear for most of the photocatalysts under working conditions. Notably that photo-generated electrons and holes transfer to the cocatalysts for chemical reactions, therefore, it is inevitable that the chemical states of the cocatalyst are changed under photocatalytic reactions. However, how the redox cocatalyst evolves under photocatalytic reaction has long been not clear.
Nickel or nickel oxide are considered as the efficient cocatalysts for photocatalytic water splitting on semiconductor-based photocatalysts [11]. It was found that the nickel-based cocatalyst in $\mathrm{K}_{4} \mathrm{Nb}_{6} \mathrm{O}_{17}$ photocatalyst was required to be pretreated by $\mathrm{H}_{2}$ and then oxidized by $\mathrm{O}_{2}$, possibly forming a Ni/NiO core/shell structured cocatalyst, which was beneficial for photocatalytic water splitting [12]. Townsend et al. [13] suggested that nickel-based cocatalyst on $\mathrm{SrTiO}_{3}$ is more likely a three components $\mathrm{Ni}-\mathrm{SrTiO}_{3}-\mathrm{NiO}$ with $\mathrm{Ni}$ as reduction cocatalyst and $\mathrm{NiO}$ as oxidation cocatalyst. Han et al. [14] recently reported that co-catalysts showed a variation from $\mathrm{Ni@NiO}$ core-shell to $\mathrm{Ni}$ and $\mathrm{NiOOH}$ species, which severed as reduction and oxidation cocatalysts on $\mathrm{SrTiO}_{3}$-based photocatalyst, respectively.

\footnotetext{
* Corresponding author. Tel: +86-411-84379070; Fax: +86-411-84694447; E-mail: canli@dicp.ac.cn

This work was supported by the Strategic Priority Research Program of Chinese Academy of Sciences (XDB17000000) and the National Natural Science Foundation of China (21761142018).
}

DOI: 10.1016/S1872-2067(18)63138-9 | http://www.sciencedirect.com/science/journal/18722067 | Chin. J. Catal., Vol. 39 , No. 11 , November 2018 
Zhang et al. [15] found more than one nickel species on equivalent facet of $\mathrm{NaTaO}_{3}$ nanocrystals. These reports on the nickel-based cocatalysts in water reduction and/or oxidation reactions were often contradictory in the literature, which is largely due to the difficulty to distinguish the exact chemical states and the surface distribution of cocatalysts under photocatalytic reactions.

Separation of dual-cocatalysts on different facets has recently been demonstrated to be an effective strategy for suppressing reverse reaction and enhancing charge separation in photocatalysis [16-20]. In this work, taking nickel deposited $\mathrm{NaTaO}_{3}$ as an example, we investigate the chemical states of nickel-based cocatalysts derived during photocatalytic water splitting reaction. An interesting photo-induced self-formation of $\mathrm{Ni}$ and $\mathrm{NiO}$ cocatalysts was found on the surface of $\mathrm{NaTaO}_{3}$ nanocrystals. The self-formation of redox dual-cocatalysts are spatially separated on the surface of $\mathrm{NaTaO}_{3}$ nanocrystals.

Two types of $\mathrm{NaTaO}_{3}$ nanocrystals were synthesized with anisotropic facets (26-facet $\mathrm{NaTaO}_{3}$ ) and isotropic facets (6-facet $\mathrm{NaTaO}_{3}$ ) [21]. Photodeposition method can be used to determine the distribution of photogenerated electrons and holes [22]. For 26-facet $\mathrm{NaTaO}_{3}$ (Fig. 1), most Pt particles were selectively deposited on $\{001\}$ facets while majority $\mathrm{Co}_{3} \mathrm{O}_{4}$ particles only appeared on $\{011\}$ and $\{111\}$ facets, suggesting that photogenerated electrons and holes can be spatially separated between different facets of $\mathrm{NaTaO}_{3}$ nanocrystals. It shows that both $\mathrm{Pt}$ and $\mathrm{Co}_{3} \mathrm{O}_{4}$ particles are all randomly deposited on all the facets of 6-facet $\mathrm{NaTaO}_{3}$ (Fig. S1), indicating that the photogenerated electrons and holes are randomly distributed on every facet. The two types of nanocrystals possess similar crystalline structures (Fig. S2), light absorption properties (Fig. S3) and surface areas etc. (Table S1). Therefore, it is feasible to investigate the chemical states of nickel-based cocatalysts according to the spatial charge separation. Fig. 1(c) shows the shape-controlled growth of 26-facet $\mathrm{NaTaO}_{3}$ nanocrystals, with smooth facet and regular morphology, exposed with $\{001\}$, $\{011\}$ and $\{111\}$ facets. Fig. 1(d) and Fig. S1(c) show 26-facet $\mathrm{NaTaO}_{3}$ and 6-facet $\mathrm{NaTaO}_{3}$ schematically. EDS of Pt or $\mathrm{Co}_{3} \mathrm{O}_{4}$
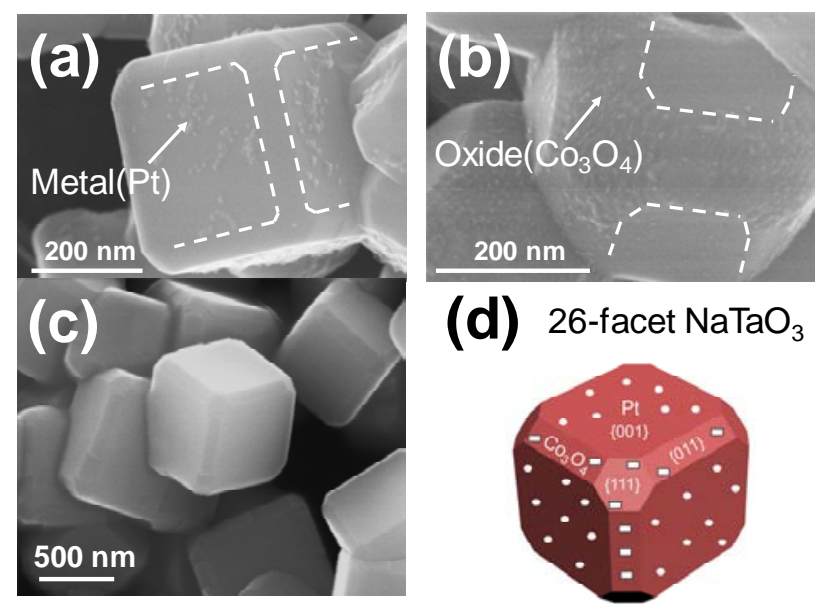

Fig. 1. Photo-reduction of $\mathrm{Pt}$ and photo-oxidation of $\mathrm{Co}_{3} \mathrm{O}_{4}$ on 26-facet $\mathrm{NaTaO}_{3}$ nanocrystals. (a) Pt/26-facet $\mathrm{NaTaO}_{3}$; (b) $\mathrm{Co}_{3} \mathrm{O}_{4} / 26$-facet Na$\mathrm{TaO}_{3}$; (c) Shape-controlled growth of 26-facet $\mathrm{NaTaO}_{3}$ nanocrystals; (d) Schematic model of 26-facet $\mathrm{NaTaO}_{3}$. deposited on 26-facet $\mathrm{NaTaO}_{3}$ are shown in Fig. S4, but part of the element Pt signal was obscured by the signal of element Ta. Therefore, XPS of Pt or $\mathrm{Co}_{3} \mathrm{O}_{4}$ deposited on 26-facet $\mathrm{NaTaO}_{3}$ are shown in Fig. S5. Pt $4 f$ in XPS revealed that the deposited element was in the metallic form. According to the binding energy of Co $2 p$ in XPS, the specie can be ascribed to $\mathrm{Co}_{3} \mathrm{O}_{4}$. The influence of different facet structure was verified by a traditional impregnation method. This method is based on the surface structure and adsorption factor. The nanoparticles are distributed on all the facets of 26 -facet $\mathrm{NaTaO}_{3}$ randomly by impregnation method (Fig. S6). However, in photodeposition method, two different nanoparticles are distributed on the surface of 26-facet $\mathrm{NaTaO}_{3}$ spatially. Therefore, this impregnation method has relatively weak influence by different facet structures when compared with photodeposition method.

As an efficient cocatalyst, nickel oxide was used to load on the surface of $\mathrm{NaTaO}_{3}$ nanocrystals by conventional impregnation method, usually this method can make the cocatalysts distribute uniformly on all the facets of nanocrystals [23-31]. EDS of cocatalysts deposited 26-facet $\mathrm{NaTaO}_{3}$ are shown in Fig. S7. But EDS cannot characterize the chemical state of nickel species, just the element nickel. Therefore, the cocatalyst was characterized by XPS before and after photo irradiation on 26-facet $\mathrm{NaTaO}_{3}$ nanocrystals further. The impregnated sample is confirmed by XPS and the result gives only the peak of $\mathrm{NiO}$ species $\left(2 p_{3 / 2}\right.$ at $854.9 \mathrm{eV}$ ) before photo illumination (Fig. 2(a)). After photo illumination with water under the protection of argon (to isolate the $\mathrm{O}_{2}$ in the air, in case the metallic Ni was oxidize by $\left.\mathrm{O}_{2}\right)$, the XPS peak of metallic $\mathrm{Ni}\left(2 p_{3 / 2}\right.$ at $\left.852.9 \mathrm{eV}\right)$ was observed. It is clear that both $\mathrm{Ni}$ and $\mathrm{NiO}$ present distinct peaks in XPS after illumination, indicating that at least part of $\mathrm{NiO}$ loaded by impregnation method can be reduced to metallic $\mathrm{Ni}$ by the photogenerated electrons during the illumination process (Fig. S8).

The impregnated $\mathrm{NiO}$ was also fully reduced by $\mathrm{H}_{2}$. Only the XPS of metallic Ni can be observed (Fig. 2(b)), suggesting that $\mathrm{NiO}$ was reduced to element $\mathrm{Ni}$. After photo illumination with water under the protection of argon, the XPS peak of NiO appears with the coexisting of metallic $\mathrm{Ni}$. It is clear that both $\mathrm{Ni}$ and $\mathrm{NiO}$ species are produced, demonstrating that part of metallic Ni has been oxidized by the photogenerated holes during the illumination process.

Fig. 3 shows the TEM images of cocatalysts species on different facets of 26-facet $\mathrm{NaTaO}_{3}$ with depositing $\mathrm{NiO}$ by impregnation method. NiO deposited by impregnation method were small particles (Fig. 3(a)). After photo illumination, most particles on $\{001\}$ facets and the species on $\{011\}$ facets manifest different morphologies between each other (Fig. 3(b)). More TEM image for cocatalysts on each facet is shown in Fig. S9. Fig. 3(c) shows that the lattices on $\{011\}$ facet match well with $\mathrm{NiO}$ (the same position as an oxidation cocatalyst $\mathrm{Co}_{3} \mathrm{O}_{4}$ in Fig. 1(b); PDF\#47-1049). Similarly, in Fig. 3(d), the lattice distance of $\mathrm{Ni}$ can be seen on $\{001\}$ facet (the same position as reduction cocatalyst Pt in Fig. 1(a); PDF\#45-1027). The separation of photogenerated electrons and holes makes the $\mathrm{Ni}$ and $\mathrm{NiO}$ dual-cocatalysts distributed on different facets. The changes of nickel species before and after photo illumination demon- 

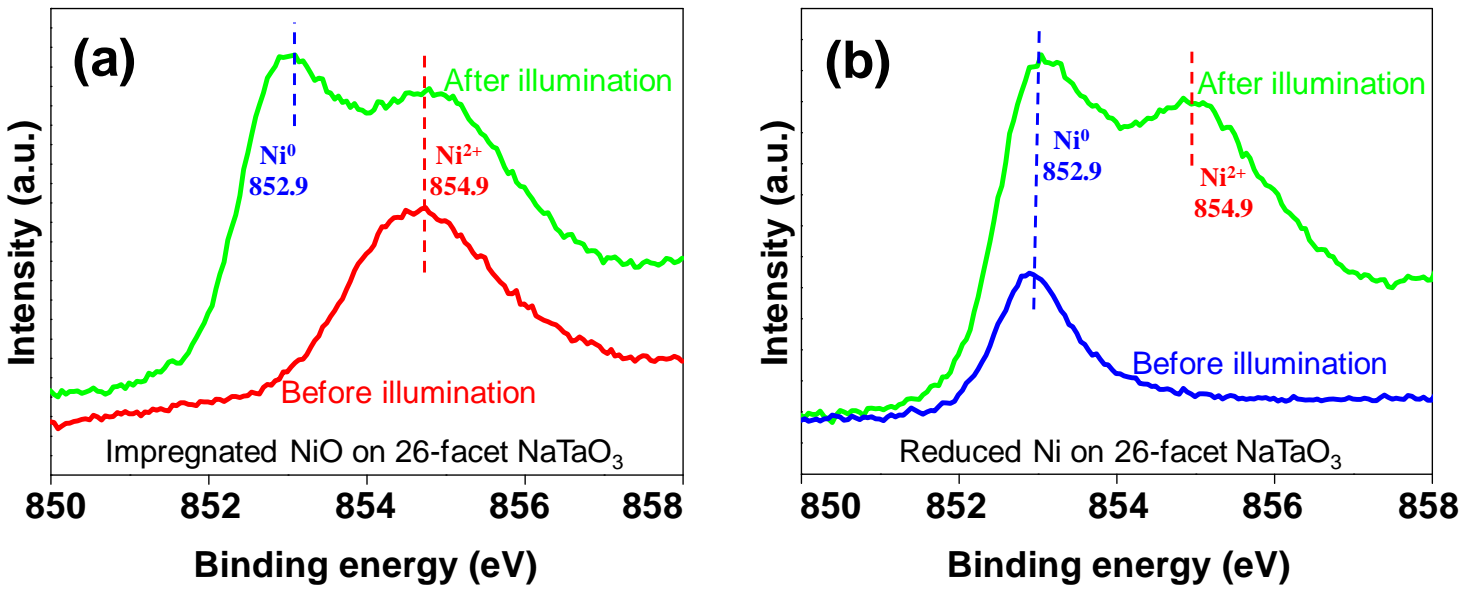

Fig. 2. XPS spectra of impregnated $\mathrm{NiO}$ (a) and reduced $\mathrm{Ni}$ (b) before and after illumination on 26 -facet $\mathrm{NaTaO}_{3}$.

strate the self-formation of $\mathrm{Ni} / \mathrm{NiO}$ dual-cocatalysts on 26 -facet $\mathrm{NaTaO}_{3}$. After reactions reach to equilibrium, $\mathrm{Ni}$ and $\mathrm{NiO}$ can be located on different facets. The above results indicate an interesting phenomenon of self-formation of $\mathrm{Ni}$ and $\mathrm{NiO}$ cocatalysts by photogenerated charges when $\mathrm{NaTaO}_{3}$ photocatalyst was excited under light irradiation.

This phenomenon can be also seen in the overall water splitting test for $\mathrm{NaTaO}_{3}$-based photocatalysts with different cocatalysts deposited. $\mathrm{NiO} / \mathrm{NaTaO}_{3}$ was prepared by impregnation method and $\mathrm{Ni} / \mathrm{NaTaO}_{3}$ by impregnation method and followed by a reduction in $\mathrm{H}_{2}$ atmosphere. For the impregnated $\mathrm{NiO} / \mathrm{NaTaO}_{3}$ photocatalyst (Fig. 4(a) and (c)), the ratio of $\mathrm{H}_{2}$ to $\mathrm{O}_{2}$ was slightly smaller than 2.0 at initial time of reaction, which means that some photogenerated electrons were consumed to

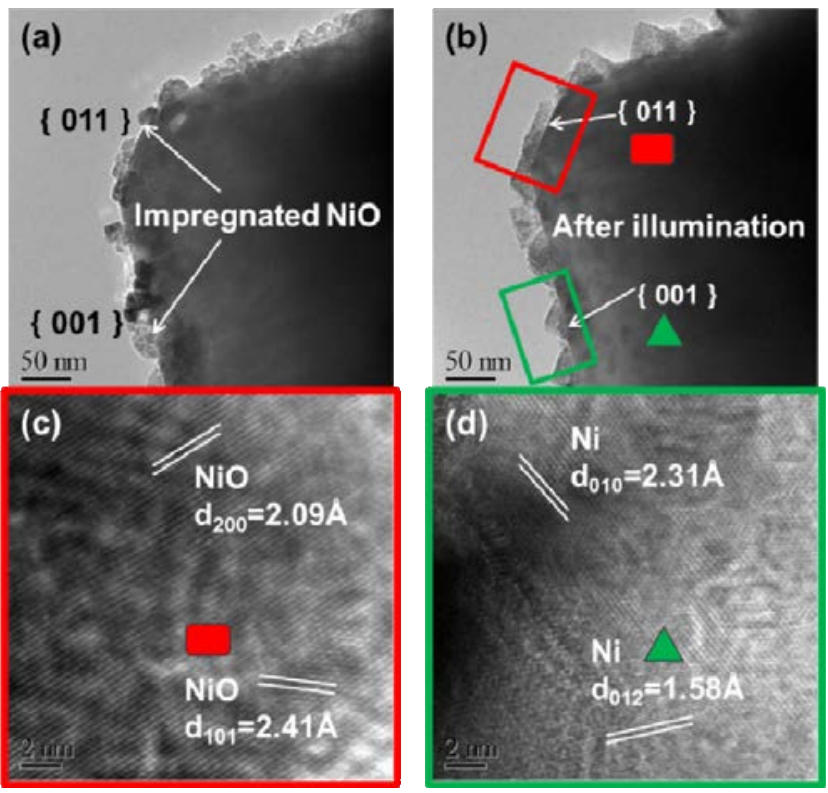

Fig. 3. TEM images show morphologies change of nickel species as cocatalysts before (a) and after (b) photo-illumination on 26-facet $\mathrm{Na}$ $\mathrm{TaO}_{3}$; (c) HRTEM images of nickel oxide as oxidation (a) and reduction (b) cocatalyst on $\{001\}$ facet. reduce $\mathrm{NiO}$ species to $\mathrm{Ni}$. As the reaction time was prolonged, the ratio of $\mathrm{H}_{2}$ to $\mathrm{O}_{2}$ reached to a stoichiometric value gradually. These processes can be described as following equations:

$$
\begin{gathered}
2 \mathrm{NiO} \text { (impregnated) }+4 \mathrm{e}^{-}+4 \mathrm{H}^{+} \rightarrow 2 \mathrm{Ni}+2 \mathrm{H}_{2} \mathrm{O} \\
\mathrm{H}_{2} \mathrm{O}+4 \mathrm{~h}^{+} \rightarrow \mathrm{O}_{2}+4 \mathrm{H}^{+}
\end{gathered}
$$

On the contrary, for the fully reduced Ni photocatalysts (Fig. 4(b) and (d)), the initial ratio of $\mathrm{H}_{2}$ to $\mathrm{O}_{2}$ was a bit greater than 2.0 because part of the photogenerated holes were consumed for oxidizing the metallic $\mathrm{Ni}$ to $\mathrm{NiO}$. The ratio of $\mathrm{H}_{2}$ to $\mathrm{O}_{2}$ was approaching to 2.0 as the oxidation of $\mathrm{Ni}$ to $\mathrm{NiO}$ reached to equilibrium. These processes can be described as following equations:

$$
\begin{gathered}
\mathrm{Ni} \text { (reduced) }+2 \mathrm{~h}^{+}+\mathrm{H}_{2} \mathrm{O} \rightarrow \mathrm{NiO}+2 \mathrm{H}^{+} \\
2 \mathrm{H}^{+}+2 \mathrm{e}^{-} \rightarrow \mathrm{H}_{2}
\end{gathered}
$$

The finial performances of two different photocatalysts are almost at the same level after photo illumination for a long time, due to the equilibrium between $\mathrm{Ni}$ and $\mathrm{NiO}$.

Both HRTEM and photocatalytic water splitting results evidence a self-formation phenomenon of $\mathrm{Ni}$ and $\mathrm{NiO}$ species on 26-facet $\mathrm{NaTaO}_{3}$ photocatalyst under the light irradiation, which was also demonstrated by XPS characterization. On 6-facet $\mathrm{NaTaO}_{3}$ nanocrystals with isotropic facets exposed (Fig. 5(a)), HRTEM images show different morphologies of the nickel species after photo illumination. Similar to the cocatalysts on 26-facet $\mathrm{NaTaO}_{3}$, it can be found that different morphologies of cocatalysts appear on the surface of 6-facet $\mathrm{NaTaO}_{3}$ (Fig. 5(b)). More TEM image can be seen in Fig. S10. The lattices of the selected area in Fig. 5(b) match well with the metallic nickel and nickel oxide, respectively (Fig. 5(c)). Therefore, the self-formation of dual-cocatalysts can also occur on a more general 6-facet $\mathrm{NaTaO}_{3}$ nanocrystal with isotropic facet exposed by photogenerated electrons and holes. It should be noted that the widely-used $\mathrm{NiO}$ loaded $\mathrm{NaTaO}_{3}$ photocatalysts gives high quantum efficiency in photocatalytic overall water splitting is possibly due to the generation of redox dual-cocatalysts for improving both reduction and oxidation surface reactions.

The overall water splitting activities on different $\mathrm{Na}$ - 

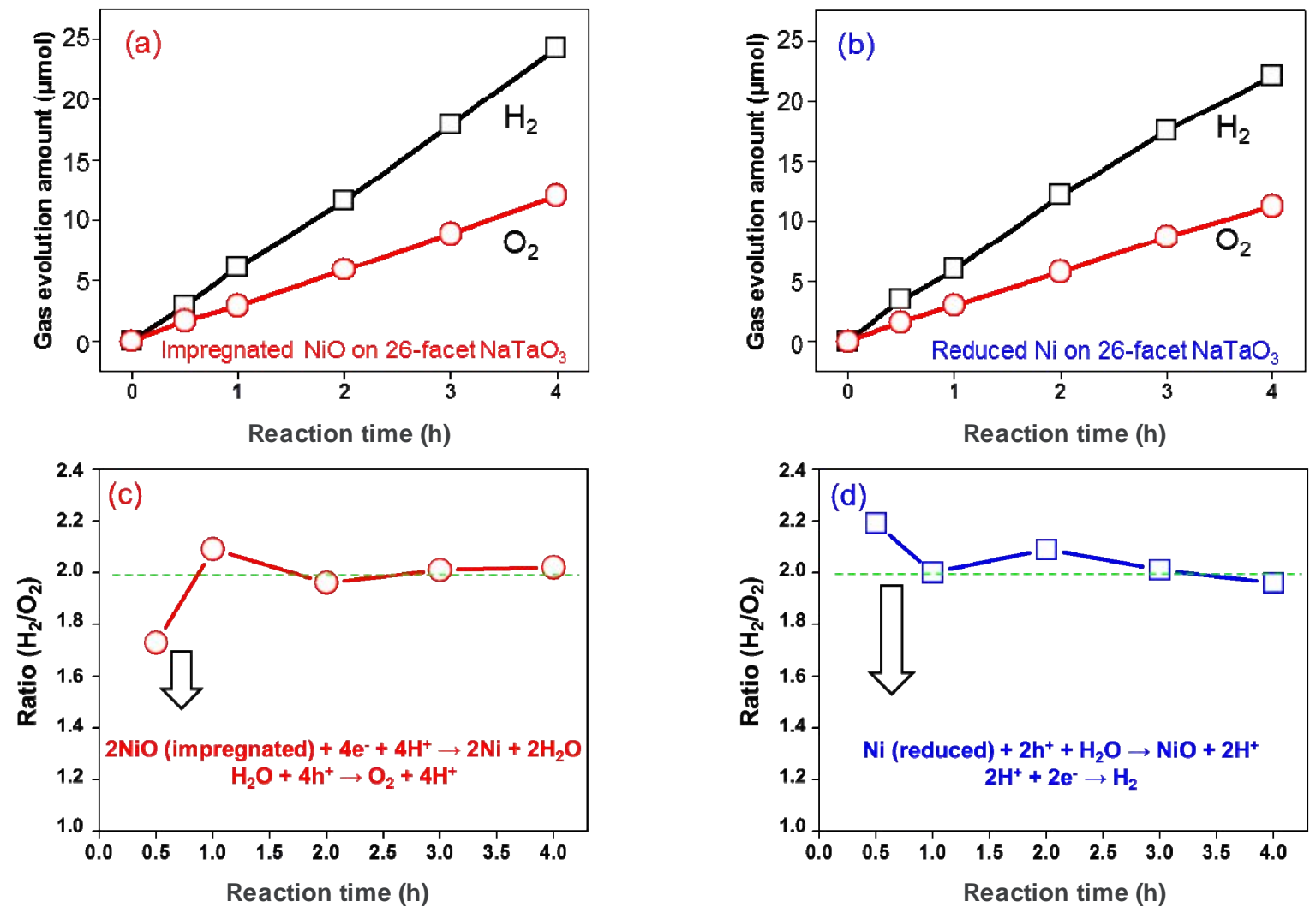

Fig. 4. Average photocatalytic overall water splitting activities of impregnated $\mathrm{NiO}$ (a) and reduced $\mathrm{Ni}$ (b) on 26 -facet $\mathrm{NaTaO}_{3}$. $\mathrm{H}_{2} / \mathrm{O}_{2}$ ratio of impregnated $\mathrm{NiO}$ (c) and reduced $\mathrm{Ni}$ (d) by the average photocatalytic overall water splitting performances on 26-facet $\mathrm{NaTaO}_{3}$. Irradiated by Hg-Xe lamp.

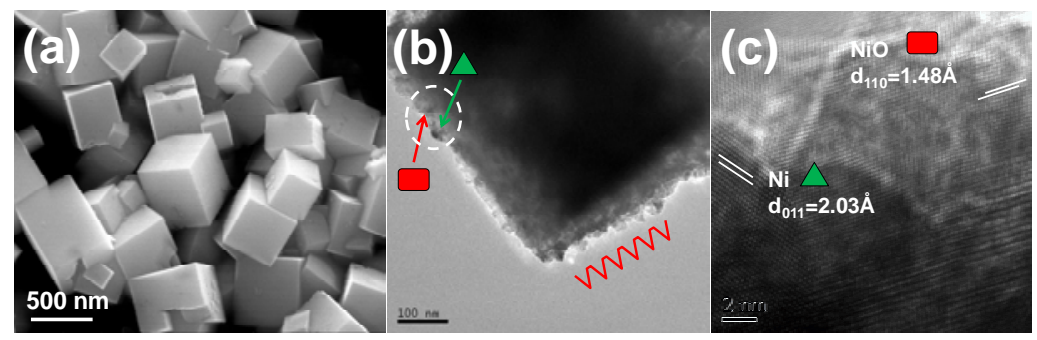

Fig. 5. (a) Shape-controlled growth of 6-facet $\mathrm{NaTaO}_{3}$ nanocrystals. (b) TEM image shows morphologies of nickel species after photo-illumination on isotropic facet of 6-facet $\mathrm{NaTaO}_{3}$. (c) Amplification of the selected area in image (b) shows nickel oxide and metallic nickel on the surface of 6-facet $\mathrm{NaTaO}_{3}$

$\mathrm{TaO}_{3}$-based photocatalysts are shown in Fig. S11. The enhancement of $\mathrm{Ni} / \mathrm{NiO}$ deposited 26-facet $\mathrm{NaTaO}_{3}$ can be attributed to the spatial charge separation between different facets. Scheme 1 describes the process of the whole charge separation on 26-facet $\mathrm{NaTaO}_{3}$ and self-formation of dual-cocatalysts on 6-facet $\mathrm{NaTaO}_{3}$. The energy diagram in Fig. $\mathrm{S} 12$ shows the functional role of $\mathrm{Ni}$ and $\mathrm{NiO}$ on $\mathrm{NaTaO}_{3}$ semiconductor. The change of suspension $\mathrm{pH}$ value before and after photocatalysis is less than 0.2 and the leaching of element nickel (peak in UV-vis spectra at $395 \mathrm{~nm}$ ) is too less to be detected in electrolyte after photo reaction. The reduction treatment of $\mathrm{NiO}$ at specific temperature won't destroy the surface structure of $\mathrm{NaTaO}_{3}$ semiconductor (Fig. S13). Therefore, the above factors have less effect in this photocatalysis system. Photore- duced metallic Ni was involved in the initial stage of photocatalytic overall water splitting, and the equilibrium between metallic nickel and nickel oxide as well as their location sites are crucial factors influencing the whole processes. At the beginning, NiO was impregnated uniformly on every facet. Subsequently, the photogenerated electrons reduce the nickel oxide to metallic state. This interesting phenomenon of self-formation for $\mathrm{Ni}$ and $\mathrm{NiO}$ cocatalysts by photogenerated charges not only takes place on 26-facet $\mathrm{NaTaO}_{3}$, but also occurs on a more general 6-facet $\mathrm{NaTaO}_{3}$.

In summary, taking nickel deposited $\mathrm{NaTaO}_{3}$ as an example, we investigated the chemical state of nickel-based cocatalysts derived under working conditions. Interestingly, it was found that photo-induced self-formation of $\mathrm{Ni}$ and $\mathrm{NiO}$ cocatalyst spe- 

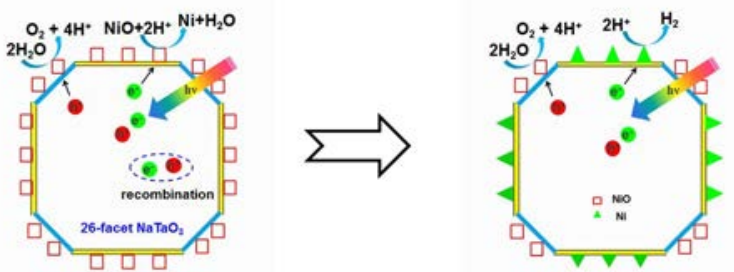

a. Charge separation between different facets of 26-facet $\mathrm{NaTaO}_{3}$


b. Self-derivation of redox dual-cocatalysts on 6-facet $\mathrm{NaTaO}_{3}$

Scheme 1. Schematic description of (a) spatial charge separation between different facets of 26-facet $\mathrm{NaTaO}_{3}$ and (b) self-formation of $\mathrm{Ni} / \mathrm{NiO}$ redox dual-cocatalysts on 6 -facet $\mathrm{NaTaO}_{3}$ by photogenerated charges.

cies on the surface of $\mathrm{NaTaO}_{3}$ nanocrystals during photocatalytic water splitting reaction. The self-formation of dual-cocatalysts not only occurs on 26-facet $\mathrm{NaTaO}_{3}$, but also takes place on a more general 6-facet $\mathrm{NaTaO}_{3}$. These findings clarified the evolution of redox dual-cocatalysts during photocatalytic reaction in heterogeneous photocatalyst systems for solar energy conversion.

\section{Acknowledgments}

This work was supported by the Strategic Priority Research Program of Chinese Academy of Sciences (XDB17000000), the
National Natural Science Foundation of China (21761142018). Linchao $\mathrm{Mu}$ thanks the support from Haldor Topsøe A/S of Denmark.

\section{References}

[1] Y. Tachibana, L. Vayssieres, J. R. Durrant, Nat. Photonics, 2012, 6, 511-518.

[2] X. L. Wang, S. Shen, Z. C. Feng, C. Li, Chin. J. Catal., 2016, 37, 2059-2068.

[3] B. Yuan, B. Zhang, Z. L. Wang, S. M. Lu, J. Li, Y. Liu, C. Li, Chin. J. Catal., 2017, 38, 440-446.

[4] J. S. Luo, J. H. Im, M. T. Mayer, M. Schreier, M. K. Nazeeruddin, N. G. Park, S. D. Tilley, H. J. Fan, M. Gratzel, Science, 2014, 345, 1593-1596.

[5] A. Kudo, Y. Miseki, Chem. Soc. Rev., 2009, 38, 253-278.

[6] S. Y. Reece, J. A. Hamel, K. Sung, T. D. Jarvi, A. J. Esswein, J. J. H. Pijpers, D. G. Nocera, Science, 2011, 334, 645-648.

[7] K. Maeda, K. Teramura, D. L. Lu, T. Takata, N. Saito, Y. Inoue, K. Domen, Nature, 2006, 440, 295-295.

[8] J. Zhu, F. T. Fan, R. T. Chen, H. Y. An, Z. C. Feng, C. Li, Angew. Chem. Int. Ed., 2015, 54, 9111-9114.

[9] J. H. Yang, D. G. Wang, H. X. Han, C. Li, Acc. Chem. Res., 2013, 46, 1900-1909.

[10] K. Wenderich, G. Mul, Chem. Rev., 2016, 116, 14587-14619.

[11] H. Kato, K. Asakura, A. Kudo, J. Am. Chem. Soc., 2003, 125, 3082-3089.

[12] A. Kudo, K. Sayama, A. Tanaka, K. Asakura, K. Domen, K. Maruya, T. Onishi, J. Catal., 1989, 120, 337-352.

[13] T. K. Townsend, N. D. Browning, F. E. Osterloh, Energy Environ. Sci., 2012, 5, 9543-9550.

[14] K. Han, T. Kreuger, B. T. Mei, G. D. Mul, ACS Catal., 2017, 7, 1610-1614.

[15] Q. Zhang, Z. Li, S. Y. Wang, R. G. Li, X. W. Zhang, Z. X. Liang, H. X. Han, S. J. Liao, C. Li, ACS Catal., 2016, 6, 2182-2191.

[16] L. C. Mu, Y. Zhao, A. L. Li, S. Y. Wang, Z. L. Wang, J. X. Yang, Y. Wang,

\section{Graphical Abstract}

Chin. J. Catal., 2018, 39: 1730-1735 doi: 10.1016/S1872-2067(18)63138-9

Photo-induced self-formation of dual-cocatalysts on semiconductor surface

Linchao Mu, Qiao Zhang, Xiaoping Tao, Yue Zhao, Shengyang Wang, Junyan Cui, Fengtao Fan, Can Li *

Dalian Institute of Chemical Physics, Chinese Academy of Sciences;

University of Chinese Academy of Sciences

Self-distribution of redox dual-cocatalysts on semiconductor surface can be achieved by photogenerated electrons and holes. This strategy promotes the photocatalytic activity to a high level, which will be benefit for solar energy conversion system.

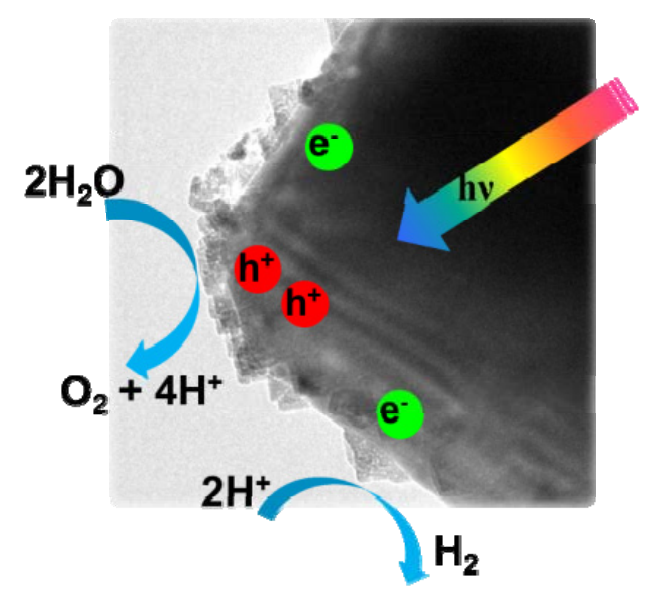


T. F. Liu, R. T. Chen, J. Zhu, F. T. Fan, R. G. Li, C. Li, Energy Environ. Sci., 2016, 9, 2463-2469.

[17] R. G. Li, H. X. Han, F. X. Zhang, D. G. Wang, C. Li, Energy Environ. Sci, 2014, 7, 1369-1376.

[18] T. Tachikawa, S. Yamashita, T. Majima, J. Am. Chem. Soc., 2011, 133, 7197-7204.

[19] D. E. Wang, H. F. Jiang, X. Zong, Q. A. Xu, Y. Ma, G. L. Li, C. Li, Chem. Eur. J., 2011, 17, 1275-1282.

[20] R. G. Li, X. P. Tao, R. T. Chen, F. T. Fan, C. Li, Chem. Eur. J., 2015, 21, 14337-14341.

[21] G. J. Liu, J. Y. Shi, F. X. Zhang, Z. Chen, J. F. Han, C. M. Ding, S. S. Chen, Z. L. Wang, H. X. Han, C. Li, Angew. Chem. Int. Ed., 2014, 53, 7295-7299.

[22] D. Y. C. Leung, X. L. Fu, C. F. Wang, M. Ni, M. K. H. Leung, X. X. Wang, X. Z. Fu, ChemSusChem, 2010, 3, 681-694.

[23] J. R. Gallagher, D. J. Childers, H. Y. Zhao, R. E. Winans, R. J. Meyer, J.
T. Miller, Phys. Chem. Chem. Phys., 2015, 17, 28144-28153.

[24] J. R. Gallagher, T. Li, H. Y. Zhao, J. J. Liu, Y. Lei, X. Y. Zhang, Y. Ren, J. W. Elam, R. J. Meyer, R. E. Winans, J. T. Miller, Catal. Sci. Technol., 2014, 4, 3053-3063.

[25] M. Cargnello, B. T. Diroll, Nanoscale, 2014, 6, 97-105.

[26] X. X. Zou, Y. Zhang, Chem. Soc. Rev., 2015, 44, 5148-5180.

[27] D. M. Fabian, S. Hu, N. Singh, F. A. Houle, T. Hisatomi, K. Domen, F. E. Osterlohf, S. Ardo, Energy Environ. Sci., 2015, 8, 2825-2850.

[28] A. G. Tamirat, J. Rick, A. A. Dubale, W. N. Su, B. J. Hwang, Nanoscale Horiz., 2016, 1, 243-267.

[29] S. S. Chen, T. Takata, K. Domen, Nat. Rev. Mater., 2017, 2, 17050.

[30] M. Cargnello, J. J. D. Jaen, J. C. H. Garrido, K. Bakhmutsky, T. Montini, J. J. C. Gamez, R. J. Gorte, P. Fornasiero, Science, 2012, 337, 713-717.

[31] L. X. Zhang, Q. L. Liu, T. Aoki, P. A. Crozier, J. Phys. Chem. C, 2015, $119,7207-7214$.

\title{
光诱导双助催化剂在半导体表面的自发形成
}

\author{
慕林超, ${ }^{\mathrm{a}, \mathrm{b}}$, 张 巧 ${ }^{\mathrm{a}}$, 陶晓萍 ${ }^{\mathrm{a}}$, 赵 越 ${ }^{\mathrm{a}, \mathrm{b}}$, 王升扬, ${ }^{\mathrm{a}, \mathrm{b}}$, 崔俊艳 ${ }^{\mathrm{a}}$, 范峰滔 ${ }^{\mathrm{a}}$, 李 灿, ${ }^{\mathrm{a},}$ \\ ${ }^{\mathrm{a}}$ 中国科学院大连化学物理研究所, 催化基础国家重点实验室, 洁净能源国家实验室(筹), \\ 能源材料化学协同创新中心, 辽宁大连116023 \\ b中国科学院大学, 北京100049
}

\begin{abstract}
摘要: 半导体光催化体系的助催化剂在光生电荷分离和表面催化反应过程中扮演着重要的角色. 然而, 在反应条件下助催 化剂的化学态是否发生改变尚不清楚. 本文以钽酸钠为模型光催化剂, 系统地研究了镍基助催化剂在光催化分解水反应 中的化学态. 结果发现, 在光诱导条件下半导体钽酸钠单晶表面自发形成了金属镍和氧化镍双助催化剂.

首先用传统的水热法合成只暴露单一晶面的六面体钽酸钠半导体单晶光催化剂和暴露不等同晶面的二十六面体钽酸 钠半导体单晶光催化剂. 原位光沉积结果显示, 暴露不同晶面的二十六面体钽酸钠半导体单晶光催化剂存在晶面间的电 荷分离现象, 进一步利用该现象可以确定不同催化活性位上镍基助催化剂的作用. XPS结果显示, 半导体钽酸钠单晶表面 的镍基助催化剂存在的不同价态. 高分辨透射电镜结果表明, 不同晶面上的镍基助催化剂具有不同的形貌, 并且通过晶格 衍射条纹的对比确认了不同镍基助催化剂物种的归属和作用.

将表面浸渍氧化镍的二十六面体钽酸钠半导体光催化剂用于全分解水测试发现, 反应开始阶段 $\mathrm{H}_{2}: \mathrm{O}_{2}$ 比值小于 $2: 1$, 说 明部分光生电子被消耗掉, 用于还原氧化镍, 生成了金属镍. 将表面还原的金属镍光催化剂进行全分解水测试发现, 反应 开始阶段 $\mathrm{H}_{2}: \mathrm{O}_{2}$ 比值大于 $2: 1$, 说明部分光生空穴被消耗掉, 用于氧化金属锦, 生成了氧化镍, 金属镍和氧化镍最终在反应的 过程中达到了平衡. 金属镍担载在 $\{001\}$ 晶面上, 起着还原助催化剂的作用, 参与质子还原, 释放出 $\mathrm{H}_{2}$; 氧化镍担载在其他 晶面上, 扮演着氧化助催化剂, 参与水的氧化, 释放出 $\mathrm{O}_{2}$; 金属镍和氧化镍共同促进了光催化全分解水反应, 使反应活性达 到了最高. 这种双助催化剂的自发形成现象不仅存在于二十六面体钽酸钠单晶半导体表面, 在六面体钽酸钠单晶半导体 表面也同样存在, 是一个普适性的现象. 在六面体钽酸钠半导体单晶光催化剂表面同样可以发现不同形貌的镍基助催化 剂, 分别归属于金属镍和氧化镍. 本文说明了助催化剂的化学态在光催化反应的条件下是可以发生改变的, 并且光生电荷 可以在半导体表面诱导双助催化剂的自发形成.
\end{abstract}

关键词: 光催化; 助催化剂; 化学态; 光生电荷; 自发形成

收稿日期: 2018-06-28. 接受日期: 2018-07-16. 出版日期: 2018-11-05.

*通讯联系人. 电话: (0411)84379070; 传真: (0411)84694447; 电子信箱: canli@dicp.ac.cn

基金来源: 中国科学院战略性先导科技专项(XDB17000000); 国家自然科学基金委员会(21761142018).

本文的电子版全文由Elsevier出版社在ScienceDirect上出版(http://www.sciencedirect.com/science/journal/18722067). 